\title{
Islamic Culture-Based Education Design in Building Muhammadiyah Students' Character
}

\author{
Akhmad Jazuli \\ Muhammadiyah University of Purwokerto, Indonesia \\ akhmadjazuli.ump@,gmail.com
}

\begin{abstract}
The phenomenon of the presence of leading schools based on Islamic culture, attract much public attention who care about character education. This study aims to examine the design of Islamic culture-based education applied in SMP Muhammadiyah in Banyumas. Two schools were selected as a sample, one school in the city area and one school outside the city area. Data collection was conducted using interviews, questionnaires and tests. Qualitative data analysis was performed using Miles and Huberman analysis, while quantitative data analysis used regression analysis. The result of the research shows that both school have set programs for students' character building through integrated Islamic culture, in learning process at classroom, education during school, and continued when students back home. However the implementation was not done properly, since the impacts of the implementation of Islamic culture had not been seen significantly.
\end{abstract}

\section{Keywords: Islamic Culture, education, Character}

\section{INTRODUCTION}

Education is a conscious and wellplanned effort to create an atmosphere of learning and learning process so that learners are actively developing their potential to have spiritual spiritual power, self-control, personality, intelligence, noble morals and skills needed by them, society, nation and state (UUSPN No.20 of 2003). In character education the education becomes an integral part of the process. Therefore it is necessary to have an educational design that involves character education.

In the process of education of the three domains, both cognitive, affective and psychomotor must be integrated proportionally if they want to take a generation of quality. A quality generation is indicated by the birth of an intelligent generation and a noble personality. Therefore soft skills and hard skills, both must walk together. The fact on the ground that one's success is more supported by soft skills than hard skills.

In realizing the goal of national education, namely that learners have spiritual spiritual power, intelligent, noble, and able to reason and think creatively in solving mathematical problems, needed a proper model of learning. One of the learning model is the learning approach based on Islamic culture. Education in Islamic culture, developed the freedom of thinking and reasoning for students who are high enough. Besides, in Islamic culturebased education, the daily activities are closely monitored related to the morals of daily, worship activities such as the implementation of prayer and reciting the Qur'an.

The results of research on junior high school students, there is a significant influence on learning achievement (Jazuli, 2012). Therefore it is suspected that the activities of Islamic culture affect the way of thinking learners. There arises a problem, how is the picture of the mathematical way of thinking of learners in Islamic Culture-Based Education (PBBI), especially in the ability problem-solving mathematically? Besides, what characters appear in the education ?, Is there any UNI impact on mathematical problem solving ability ?, is there any 
influence of UNI on the appearance of characters? Is there a characteristic relationship that emerged (developed) with the ability to solve mathematical problems?

In accordance with the research problems presented above, in general this study aims to design education based on Islamic culture as well as to analyze the linkage of character and problem solving ability of mathematical students. In detail the purpose of this study to:

a. Describe the design of Islamic CultureBased Education for students of SMP Muhammadiyah in Banyumas Regency.

b. Describe student activity of worship c. Describe the character of the developing student.

c. Describe the students' mathematical problem solving abilities.

e. Determining the influence of worship activities on the students' character values.

d. Determine the effect of character values on mathematical problem solving abilities

In Islamic Culture-Based Education, education puts forward the attainment of spiritual and intellectual abilities (Bilgrami and Asyraf, 1989). Learning in education is done cooperatively known as halaqah or learning circle group (Azra, 1999). In this learning the dignity of the students is upheld, so that the teacher positioned parallel to the learners (Maarif, 2010). This gives students opportunities, freedom of thought openly and widely. This freedom of thought encourages students to think creatively. Therefore through the UNI allegedly will be able to generate positive characters and can generate problem-solving skills, especially on solving mathematical problems.

This Islamic Culture-Based Education is an educational design that is associated with character formation and performance improvement. This educational process includes all activities at school, both in class and outside the classroom. The context of this education is issues related to Islamic culture experienced by students. The problem is related to the competence that must be mastered by the students. In the soul of Islamic culture, education is directed toward concrete or real situations. This is confirmed by Iqbal (2008) that science must begin from the concrete, and with intellectual power will give the possibility of human intelligence beyond the concrete.

The consideration of the selection of this educational approach is in line with the vision and mission of SMP Muhammadiyah in the region of Banyumas to produce qualified graduates, ie graduates who have competitive and comparative ability and have character (akhlakul karimah) in accordance with the demands of Islamic teachings. Thus, this junior high school graduate, students will have hard skills and soft skills simultaneously are needed by the people of Indonesia.

According Jazuli (2012) research results in junior Al Irsyad Purwokerto, that through learning based on Islamic culture, the ability to think mathematically very good. Even creativity in solving the problem seems clear. In line with the research, Jazuli (2013) suggests there is influence of character to the ability of creative thinking and mathematical reasoning but not vice versa. Furthermore Jazuli (2015b) suggests that there is a moral relationship and mathematical thinking. The better morals the better the ability to think mathematically.

This encourages researchers, to design an Islamic culture-based education, complete with the steps so that it appears clear in building character (character) and able to build student intelligence. This research was conducted at SMP Muhammadiyah in Banyumas district.

Mathematical Problem Solving Abilities. A problem usually contains a situation that drives people to solve it. But do not know directly what to do. A problem for someone is not necessarily a problem for others. Likewise the problem of today is not necessarily a problem on another day. Therefore it can be said that problem solving 
means solving problems in an unusual / unusual way (Fisher, 1995).

Problem solving in mathematics has two meanings: problem solving as an approach or learning strategy and problem solving as ability or activity. According to Killen (1998) it is important to make a clear distinction between teaching problem solving and using problem solving as a strategy in teaching. Teaching problem solving is teaching students how to solve problems. This case is often used by teachers in teaching mathematics and science. While problemsolving as a teaching strategy is a technique in which problems are used intentionally to assist students in understanding or relating understanding into the subjects they are studying. As an approach to learning, problem solving is used to reinvent and understand mathematical concepts / materials. Learning begins by presenting a contextual problem or situation.

Mathematical problem solving is a process in solving mathematical problems. Mathematics itself is a science that is more concerned with the process than the result or answer itself, because of the answers given will be known from where the answer was obtained. A situation is said to be a problem for a person if he or she is aware of the existence of the situation, and acknowledges that the situation requires action to quickly find its solution (Bell, 1981). A particular situation can be a problem for a particular person but not necessarily a problem for others. Likewise a situation may be a problem for a person at any given time, but not necessarily a problem for him at different times (Kusumah, 2008).

Problems in mathematics are divided into two kinds, namely: routine problems and problems are not routine. Routine problems are solely problems that can be solved directly by using several steps or algorithms, whereas the problem is not routine is a challenging problem and required the ability of creativity to solve it, because it can not be solved directly.
The stages of problem solving, according to Polya (1973) as follows: (1) understanding the problem (understand the problem); (2) devising a plan; (3) carrying out the plan; (4) looking back (checking process and outcome). Ruseffendi (1998) modified Polya's steps as follows, (1) rewriting the problem with his own words; (2) write the equation; (3) to write their solutions as solutions; (4) discuss ways of settlement; (5) working on; (6) re-check the results; (7) choose the solution.

The development of problem-solving skills is related to the development of subject comprehension, which will arise if students can think about what they are doing and why they are doing it (Killen, 1998). For effective problem solving, students need to develop their ability to understand the problem; plan how to solve problems; implement the plan; and check that the settlement is possible. Based on the above problem-solving studies it can be concluded that the ability to solve mathematical problems is the ability to solve problems by identifying problems, planning solutions, solving problems, and checking out the solutions.

Character is the values of human behavior related to God, self, fellow human, environment, and nationality embodied in thoughts, attitudes, feelings, words, and deeds based on religious norms, law, etiquette, culture and customs kemendikbud, 2011). Character education is a system of inculcating the values of character to the school community which includes the components of knowledge, awareness or willingness, and actions to implement those values, both to God Almighty (God), self, fellow, environment, and nationality so become human beings kamil (kemendikbud. 2011)

During this time, informal education, especially in the family environment has not contributed significantly in supporting the achievement of competence and character formation of learners. The busyness and activity of parents are relatively high, the lack of understanding of parents in educating 
children in the family environment, the influence of interaction in the environment, and the influence of electronic media is suspected to negatively affect the development and achievement of student learning outcomes. One alternative to overcome these problems is through integrated character education, which combines and optimizes the informal education activities of the family environment with formal education in schools. In this case, the students' learning time in school needs to be optimized in order to improve the quality of learning achievement, especially in forming the character of learners.

Character education aims to improve the quality of education implementation and outcomes in schools that lead to the achievement of character formation and noble character of learners intact, integrated, and balanced, as per the competency standards of graduates. Through character education students are expected to be able to independently improve and use their knowledge, review and internalize and personalize the values of character and noble character that manifested in everyday behavior (permendikbud no.22 year 2016).

.Character education at the institutional level leads to the establishment of a school culture, the values that underlie behavior, traditions, daily habits, and symbols practiced by all the citizens of the school, and the communities around the school. School culture is a characteristic, character or character, and the image of the school in the eyes of the wider community. Thus, the notion of character associated with school culture in this study is morals.

Moral in terminology means the behavior of a person who is driven by a conscious desire to do a good deed (Young, 2006). Morals as a behavior must be done repeatedly, so that one can be said to morals if the behavior arises by itself that is driven by motivation from within and done without much consideration of thought. In other words morals are human behavior that is done without engineering (Sauri, 2011), as a personal form of Muslims. Good measure of bad morals is viewed from the point of religious teachings that originate in Alqur'an and Assunah. More firmly said that the teachings of religion is a good morality (Khaled, 2010). People who practice religion well, will produce good morals. There are 18 values of cultural education and character of the nation are: (1) religious, (2) honest; (3) tolerance; (4) discipline; (5) hard work; (6) creative; (7) independent; (8) democratic; (9) curiosity; (10) the spirit of nationalism, (11) the love of the motherland; (12) communication; (13) love of peace; (14) appreciate achievement; (15) likes to read; (16) care about the environment; (17) social responsibility (18) responsibilities (kemendikbud, 2011). The eighteen values can be grouped in characters for personal and social environment.

Islamic culture is an activity undertaken by Muslims so far not deviate from the teachings of Islam. According Asy'arie (1999) culture can be seen from two sides as a process and as a product. Culture as a process is the creative of the human self involved in the life force that moves the body, mind, emotions, conscience and soul in a wide variety of life activities, covering social, economics, politics, science and technology and religion. Culture in the sense of products, is the incarnation of values in the form of: (1) ideas, concepts or theories; (2) activities of daily life; (3) cultural objects.

Many experts define the Islamic culture. Al-Sharqawi (1986) said that Kebudayan Islam is a culture that colored the teachings of Islam in its position as aqidah and methods of life. According to Hasjmy (1993) Islamic culture is the embodiment of the mind and sense of the Muslims, which means also that the Islamic culture is sourced on the Muslims. Thus it can be defined that Islamic Culture is the embodiment of faith and charity sholih of the Islamic or a group of Muslims. Islamic culture originated in Alqur'an and Assunah, so that all results, style 
and variety of cultures as opposed to Alqur'an and Assunah excluding Islamic culture.

Culture as a set of values, rules, norms, laws, mindsets, is a concept produced through the process of accumulation, the transformation of values that wrestle into one form a culture. Among these values the greatest contribution is the value of religion. Therefore, Islamic culture becomes important to be the basis in education (Nata, 2009).

The learning process is part of Education. Cultural-based learning will give birth to learners who have a character that is the overall rational dynamics with a variety of dimensions, both from within and from outside himself. A person can increasingly live his or her freedom and be responsible for the growth of himself as a person and as a member of society (Nata, 2009).

According to Ramayulis and Nizar (2009) that learning in Islam is dynamic. The Islamic method of education greatly values individual freedom, as long as it is in line with His nature. The educator must be responsible in shaping the character of the learner. Therefore, Islamic-based education takes place in the classroom as well as outside the classroom. According to Jazuli (2015a) Islamic culture-based education can build the character of students and at the same time build the character of the nation.

\section{METHODS}

This research uses qualitative and quantitative descriptive method. By taking the population of SMP Muhammadiyah in the district of Banyumas. Samples were selected for two schools, one in the city area and one outside the city. Each school is selected by one class in grade 8. Data collection uses questionnaires, tests, and in-depth interviews with principals, teachers, and students. Data analysis is qualitative using Miles and Huberman's steps. While the quantitative data analysis using regression analysis

\section{DISCUSSION}

a. The concept of education based on Islamic culture, from the results of interviews to principals and teachers obtained the following conclusions: Character education is done thoroughly for 24 hours, both at school and at home which include:

1) Character education in schools, including:

a) Students are handshaking with teachers when coming and going home from school.

b) Students every day are required to pray in congregation in the school mosque.

c) Students are trained honestly with the availability of honesty stalls.

d) Students must follow the recitation every Friday morning.

e) Classes of men and women separated.

f) Students must follow bibaq (guidance read Alquran).

2) Character education in learning, including:

a) The 15-minute classroom attendant in the class before the lesson begins to provide motivation to the students.

b) Master leads prayer before and after learning.

c) Guardians lead reading the Qur'an 10 minutes before the lesson begins.

d) The teacher recommends not cheating when replicating.

3) Character education at home, including:

a) The five day prayer activities are monitored with a liaison book.

b) The reading of the Qur'an is monitored with a liaison book. 
c) The existence of home visits conducted by homeroom teachers to establish communication between schools and parents.

This is a concept formulated by the school to shape the character of the student. Based on the results of questionnaires and interviews to students, it can be concluded that not all components of the activity is implemented, Similarly, some of the activities that have been implemented have not been done optimally.

Components that have not been implemented include (1) home visits, on the grounds that parents are difficult to find and (2) liaison books, on the grounds that students are not supportive. Not doing these components means that the students' activities at home can not be controlled.

The activities that have been done but not yet maximally are: (1) reading the Qur'an at the beginning of less controlled learning, (2) Duhur prayers in less controlled congregations, (3) honesty stalls not evaluated, and (4) non-cheating suggestions there is a follow-up.

b. Worship

Table 1: Activities Students of Muhammadiyah SMP outside the city

\begin{tabular}{|l|l|l|}
\hline Activity & Number & $\begin{array}{l}\text { Description (if } \\
\text { any) }\end{array}$ \\
\hline Shubuh & $8 \%$ & \\
\hline Duhur & $70 \%$ & $\begin{array}{l}\text { Students are } \\
\text { still in school }\end{array}$ \\
\hline Ashar & $6 \%$ & \\
\hline Maghrib & $40 \%$ & \\
\hline Isya & $8 \%$ & \\
\hline $\begin{array}{l}\text { Reading the } \\
\text { Qur'an daily }\end{array}$ & $0 \%$ & \\
\hline $\begin{array}{l}\text { Reading each } \\
\text { prayer will do } \\
\text { the job }\end{array}$ & $15 \%$ & \\
\hline
\end{tabular}

In Muhammadiyah Junior High School students outside the city area, only $6 \%$ of students practice 5 daily prayers per day. Unless prayers Duhur reach $70 \%$ because it is implemented when students are still in school. There are as many as $30 \%$ of students who do not care to pray. Almost $100 \%$ of students do not read the Qur'an at home. This is probably the parents did not order the child to read the Qur'an besides the child also has no consciousness. There are already $15 \%$ of students who claim to have done every prayer will do the activity.

Table 2: Students Activities of

Muhammadiyah SMP in the city

\begin{tabular}{|c|c|c|}
\hline Activity & Number & $\begin{array}{l}\text { Description (if } \\
\text { any) }\end{array}$ \\
\hline Shubuh & $27 \%$ & \\
\hline Duhur & $93 \%$ & $\begin{array}{l}\text { Students are still } \\
\text { in school }\end{array}$ \\
\hline Ashar & $27 \%$ & \\
\hline Maghrib & $60 \%$ & \\
\hline Isya & $60 \%$ & \\
\hline $\begin{array}{l}\text { Reading the } \\
\text { Qur'an daily }\end{array}$ & $7 \%$ & \\
\hline $\begin{array}{l}\text { Reading each } \\
\text { prayer will do } \\
\text { the job. }\end{array}$ & $30 \%$ & \\
\hline \multicolumn{3}{|c|}{ In the students of SMP } \\
\hline \multicolumn{3}{|c|}{$\begin{array}{l}\text { Muhammadiyah in the city area, it } \\
\text { appears that there are already } 27 \% \text { of } \\
\text { students who perform prayers } 5 \text { time. } \\
\text { Only } 7 \% \text { of students do not care about }\end{array}$} \\
\hline \multirow{2}{*}{\multicolumn{3}{|c|}{$\begin{array}{l}\text { prayer. Already there are } 7 \% \text { of } \\
\text { students who get used to reading the } \\
\text { Qur'an at home and already there are } \\
30 \% \text { of students who get used to pray }\end{array}$}} \\
\hline & & \\
\hline \multicolumn{3}{|c|}{ when will do something. } \\
\hline \multirow{3}{*}{\multicolumn{3}{|c|}{$\begin{array}{l}\text { Overall SMP Muhammadiyah in } \\
\text { urban areas is better than SMP } \\
\text { Muhammadiyah outside the city area } \\
\text { in terms of implementation of }\end{array}$}} \\
\hline & & \\
\hline & & \\
\hline \multicolumn{3}{|c|}{$\begin{array}{l}\text { In the matter of worship, it can } \\
\text { generally be concluded: }\end{array}$} \\
\hline
\end{tabular}


a) Students have not performed the prayer 5 times well

b) Students have not used to read the Qur'an at home every day

c) Students have not used to pray in every activity.

d) Activity in school has not become Islamic culture

It can be analyzed as follows,

a) Due to the unused use of the liaison book, the student's activities at

home are not monitored.

b) The result is not done home visite, so communication of school and parent disconnected.

c) As a result there is no coaching from the school to parents, so parents

do not care about the education of their children.

d) Due to the lack of supervision of teachers to students in schools, so that the Islamic culture has not gone well.

\section{c. Character}

Table 3. Attitude Character of Students of SMP Muhammadiyah Outside the City Area

\begin{tabular}{|l|l|l|}
\hline Attitude & Number & $\begin{array}{l}\text { Description } \\
\text { (if any) }\end{array}$ \\
\hline Be honest & $31 \%$ & \\
\hline $\begin{array}{l}\text { The spirit of } \\
\text { learning }\end{array}$ & $30 \%$ & Enough \\
\hline $\begin{array}{l}\text { Untrusted } \\
\text { establishment of }\end{array}$ & $40 \%$ & Enough \\
\hline Responsible & $31 \%$ & Good \\
\hline $\begin{array}{l}\text { Appreciate } \\
\text { others }\end{array}$ & $55 \%$ & Good \\
\hline Likes to help & $50 \%$ & Enough \\
\hline $\begin{array}{l}\text { Working } \\
\text { together }\end{array}$ & $70 \%$ & \\
\hline $\begin{array}{l}\text { Listen when } \\
\text { taught teacher }\end{array}$ & $70 \%$ & $52 \%$ \\
\hline $\begin{array}{l}\text { Obedience to } \\
\text { the mother and } \\
\text { the father }\end{array}$ & & \\
\hline
\end{tabular}

In Muhammadiyah SMP students outside the city area, only a good attitude of cooperation and followed the listening attitude of teachers when taught.

Table 4. Students Attitude of SMP Muhammadiyah Within the City Area

\begin{tabular}{|c|c|c|}
\hline Attitude & number & $\begin{array}{l}\text { Description (if } \\
\text { any) }\end{array}$ \\
\hline Be honest & $39 \%$ & \\
\hline $\begin{array}{l}\text { The spirit of } \\
\text { learning }\end{array}$ & $27 \%$ & \\
\hline $\begin{array}{l}\text { Untrusted } \\
\text { establishment of }\end{array}$ & $61 \%$ & Enough \\
\hline Responsible & $31 \%$ & \\
\hline Appreciate others & $61 \%$ & Enough \\
\hline Likes to help & $58 \%$ & Enough \\
\hline Working together & $76 \%$ & Good \\
\hline $\begin{array}{l}\text { Listen when taught } \\
\text { teacher }\end{array}$ & $45 \%$ & \\
\hline $\begin{array}{l}\text { Obedience to the } \\
\text { mother and the } \\
\text { father }\end{array}$ & $58 \%$ & Enough \\
\hline
\end{tabular}

In Muhammadiyah junior high school students in urban areas, only cooperative attitude is good.

Based on the above data, it can be concluded that the character of students in the city and outside the city is relatively the same. It's just that the out-of-town students pay more attention when teachers are taught. Generally

it can be said that the level of student character on the category enough. This is possible as follows: (i) Character building program through worship activity is still low. (ii) The quality of teachers (mentors) still needs to be improved. (iii) Implementation Lack of discipline, lack of supervision. (iv) Activities of worship activities are still a burden on students, not necessarily. (v) The absence of unity between schools, teachers and parents, in the implementation of the program. 
1)

Mathematical Problem Solving Abilities

The conclusion of the result of student work analysis in problem solving for SMP Muhammadiyah. Both outside city area and within city area are as follows:

1) Low communication

2) Low self-esteem

3) Not persistent

4) The order of resolution of irregular questions

5) Answers tend to be wrong

d. The linkage of character values with students' mathematical problem solving abilities.

This discussion is used regression analysis, the following results are obtained:

Table 5: Influence the value of Character to The Ability of problem solving

Coefficients $^{\mathrm{a}}$

\begin{tabular}{|c|c|c|c|c|c|}
\hline \multirow[b]{2}{*}{ Model } & \multicolumn{2}{|c|}{$\begin{array}{l}\text { Unstandardized } \\
\text { Coefficients }\end{array}$} & \multirow{2}{*}{$\begin{array}{c}\begin{array}{c}\text { Standardized } \\
\text { Coefficients }\end{array} \\
\text { Beta }\end{array}$} & \multirow[b]{2}{*}{$t$} & \multirow[b]{2}{*}{ Sig. } \\
\hline & B & $\begin{array}{l}\text { Std. } \\
\text { Error }\end{array}$ & & & \\
\hline (Constant) & 64.211 & 8.127 & & 7.90 & .000 \\
\hline Karakter & -.148 & .196 & -.103 & -.756 & .453 \\
\hline
\end{tabular}

$\mathrm{Y}=64.211-0.148 \mathrm{X} 1$

$\mathrm{Y}$ : problem solving/ learning

achievement

$\mathrm{X} 1$ : character value.

Based on the regression equation, the character value has no effect on learning achievement / problemsolving abilities.
Table 6..Influence The Value of Character And Worship To The Ability of Problem

Solving

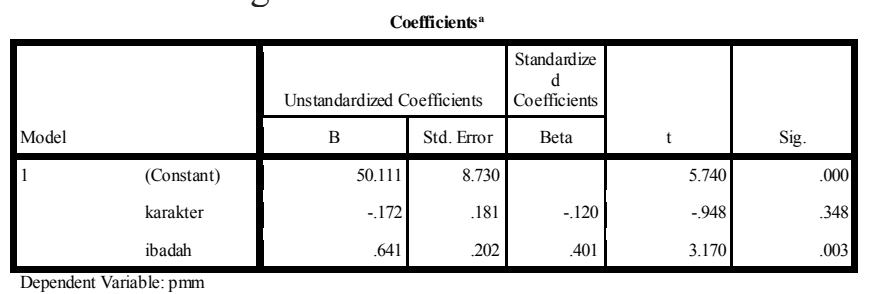

$\mathrm{Y}=50.111-0.172 \mathrm{X} 1+0.641 \mathrm{X} 2$

$\mathrm{Y}$ : problem solving / learning achievement

$\mathrm{X} 1$ : character value

$\mathrm{X} 2$ : the value of worship

Based on the above regression equation, it can be concluded that the character. no effect on learning achievement. While the value of worship effect on learning achievement / problem solving ability.

SMP Muhammadiyah within the city area.

Table 7.. Influence The Value of character To The Ability of Problem Solving

\begin{tabular}{|c|c|c|c|c|c|}
\hline & \multicolumn{3}{|c|}{ Coefficients $^{\mathrm{a}}$} & \multirow{3}{*}{$\mathrm{T}$} & \multirow{3}{*}{ Sig. } \\
\hline \multirow[b]{2}{*}{ Model } & \multicolumn{2}{|c|}{ Unstandardized Coefficients } & $\begin{array}{c}\text { Standardized } \\
\text { Coefficients }\end{array}$ & & \\
\hline & B & Std. Error & Beta & & \\
\hline (Constant) & 74.888 & 6.405 & & 11.691 & .000 \\
\hline karakter & -.335 & .156 & -.370 & -2.142 & .041 \\
\hline
\end{tabular}

$\mathrm{Y}=74,889-0,335 \mathrm{X}$

$\mathrm{Y}$ : the value of problem-solving abilities

$\mathrm{X}$ : character value

The characters have no effect on the learning achievement or problemsolving abilities. 
Table 8. Influence The Value of Character And Worship To The Ability of Problem Solving

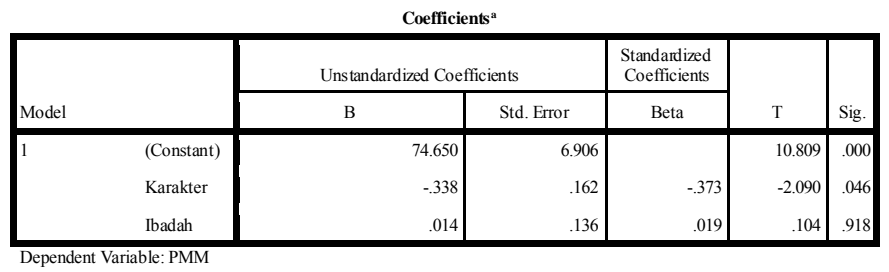

$\mathrm{Y}=74,650-0,338 \mathrm{X} 1+0,014 \mathrm{X} 2$

$\mathrm{Y}$ : the value of problem solving

abilities / learning achievement.

$\mathrm{X} 1$ : character value

$\mathrm{X} 2$ : the value of worship

Activities of worship affect the learning achievement / problemsolving skills although not significant, while the character has no effect on learning achievement / problemsolving abilities.

Thus, overall both Muhammadiyah SMP outside city and city, the character has no effect on learning achievement.

\section{CONCLUSION}

a. The design of Islamic culture-based education for SMP Muhammadiyah in Banyumas district covers 3 components, that is education for students in school, education during the students follow the learning process in the classroom, and the students' education when they are at home.

b. The concept of education based on Islamic culture in the SMP Muhammadiyah neighborhood of Banyumas district already exists, but has not been implemented properly.

c. Implementation of character building through education based on Islamic culture has been implemented in part and has not give positive impact to student's learning behavior and achievement.

\section{SUGGESTIONS /}

\section{RECOMMENDATIONS}

a. Need to find a way out to be able to carry out all the plans that have been programmed, so the formation of characters through education-based Islamic culture can be run.

b. Need to evaluate programs that have been planned and reviewed more thoroughly to obtain input from various parties.

c. Various alternatives for improvement of character formation programs / morals are as follows:

1) Home visit needs to be implemented as planned.

2) The liaison should be activated to determine the activities of the students.

3) Regular guardian meeting is necessary to unite understanding between school, teacher and parents.

4) The need for rules that bind the teachers in terms of moral guidance, so that teachers have certainty in the work

5) The workplace homeroom should be integrated into the class so that the homeroom teacher can monitor students at all times.

6) Warung kejujuran can be done but with the monitoring of the school

so that it can be evaluated periodically

\section{REFERENCES}

Al-sharqawi, E. (1986). Filsafat Kebudayaan Islam.Bandung: Pustaka

Asy'arie, M. (1999). Filsafat Islam tentang Kebudayaan.Yogyakarta: LESFI

Azra, A.(1999). Pendidikan Islam Tradisi

Dan Modernisasi Menuju Millennium Baru. Jakarta:Logos Wacana Ilmu.

Bell F.H. (1981). Teaching and Learning Mathematics in The Secondary 
School. New York :Wm.C.Brown Company Publiser

Bilgrami, H.H. dan Asyraf, S.A.(1989).The concept of Islamic University Wacana

(terjemahan), Yogyakarta:Tiara

Hasjmy, A.(1993) Sejarah Kebudayan Islam. Jakarta: Bulan Bintang Iqbal, M. (2008). Rekonstruksi Pemikiran Agama dalam Islam (terjemahan). Yogyakarta: Jalasutra

Jazuli, A. (2012) Gambaran Kemampuan Matematis, Akhlak, dan Prestasi Belajar Matematika Siswa SMP dalam Pembelajaran Berbasis Budaya Islam. Disertasi SPs UPI. Tidak diterbitkan.

Jazuli, A. (2015a) Pendidikan Matematika Berbasis Budaya Islam Dalam Membentuk Karakter Bangsa. Prosiding ISBN 978-602-14377-3-5

Jazuli, A (2013). Description of Mathematical Creative Thinking and Reasioning of SMP Student In Islamic Culture Based Learning. Educare vol 5 ISSN 19797877 Februari 2013

Jazuli, A. (2015b) Keterkaitan Akhlak dan Kemampuan Berpikir Matematis Siswa SMP Dalam Pendidikan Berbasis Budaya Islam. Prosiding ISBN 602199224-7

Kemendikbud (2011) Pedoman Pelaksanaan Pendidikan Karakter, Jakarta:Puskur

Khaled, A. (2010) Buku Pintar Akhlak (terjemahan). Jakarta: Zaman
Killen, R. (1998). Effective Teaching Strategies, Australia : social science press.

Kusumah,Y.S. (2008), Konsep, Pengembangan, dan Implementasi Computer Based Learning dalam Peningkatan Kemampuan High-Order Mathematical Thinking (Pidato Pengukuhan Jabatan Profesor, 23 Oktober 2008), Bandung : UPI

Maarif, A.S. (2010). Islam dalam Bingkai Keindonesiaan dan Kemanusiaan. Bandung: Mizan.

Nata, A. (2009). Ilmu Pendidikan Islam dengan Pendekatan Multidisipliner. Jakarta: Rajawali Press.

Permen dikbud no.22 tahun 2016 tentang proses pembelajaran.

Polya, G. (1973). How To Solve It ( $2^{\text {nd }}$ ed). Princeton: Princeton University Press

Ramayulis, dan Nizar, S. (2009) Filsafat Pendidikan Islam. Jakarta: Kalam Mulia.

Ruseffendi (1998). Pengantar Kepada Membantu Guru Mengembangkan Kompetensinya Dalam Pengajaran Matematika Untuk Meningkatkan CBSA. Bandung: Tarsito

Sauri, S. (2011) Filsafat dan Teosafat Akhlak. Bandung: RIZQI Press.

Fisher, R (1995) Teaching Children To Think. Hongkong:Stanley Thomas Ltd.

UUSPN No. 20 tahun 2003 